\title{
Jenynsia luxata, a new species from Northwestern Argentina, with additional observations of $J$. maculata Regan and phylogeny of the genus (Cyprinodontiformes: Anablepidae)
}

\author{
Gastón Aguilera ${ }^{1}$, Juan Marcos Mirande ${ }^{1}$, Pablo A. Calviño ${ }^{2}$ and Luis Fernando Lobo ${ }^{1}$
}

\begin{abstract}
Jenynsia luxata, a new species from northwestern Argentina, is described. This species is diagnosable from all other Jenynsia by the medial processes of left and right pelvic bones relatively reduced and separated from each other. The new species resembles $J$. multidentata, but it is further distinguished from this species by the absence of a swelling between the urogenital opening and the anterior base of the anal fin in females and details of coloration. Phylogenetic analyses, both under implied and equal weighting, recover the subgenera Plesiojenynsia and Jenynsia as monophyletic units. New information on previously missing characters of Jenynsia maculata is added. These data and phylogenetic characters coded for the new species herein described contribute to a better resolution of the phylogenetic relationships within the subgenus Jenynsia, which is herein supported by additional synapomorphies relative to previous phylogenies.
\end{abstract}

Jenynsia luxata, una nueva especie del noroeste de Argentina, es descripta. Esta especie es diagnosticable por presentar los procesos mediales de los huesos pélvicos izquierdo y derecho relativamente reducidos y separados. La nueva especie se parece a J. multidentata, pero se distingue de ésta por la ausencia de un abultamiento entre la abertura urogenital y la base de la aleta anal en hembras y por detalles en el patrón de coloración. Los análisis filogenéticos, tanto bajo pesos implicados como iguales, recuperan los subgéneros Plesiojenynsia y Jenynsia como unidades monofiléticas. Se aporta nueva información sobre caracteres de $J$. maculata previamente codificados como entradas faltantes. Esos datos y los caracteres filogenéticos codificados para la nueva especie aquí descripta contribuyen a una mayor resolución de las relaciones filogenéticas dentro del subgénero Jenynsia, que está aquí soportado por sinapomorfías adicionales en relación a las filogenias previas.

Key words: Pelvic bones, Phylogeny, Systematics, Taxonomy, Tucumán.

\section{Introduction}

The number of species of the anablepid genus Jenynsia Günther has been increased in the last few years to thirteen, with the description of $J$. diphyes Lucinda, Ghedotti \& Graça (Lucinda et al., 2006). Jenynsia includes small viviparous fishes that possess tricuspidate teeth in the outer mandibular series in adults and an unscaled tubular gonopodium formed principally by anal-fin rays 3, 6, and 7 (Parenti, 1981).

The species of the genus Jenynsia are distributed latitudinally in South America from Rio de Janeiro, Brazil to Río Negro, Argentina, and longitudinally from coastal Atlantic drainages at sea level to rivers bordering the Andean region from southern Bolivia to central Argentina, reaching up to almost 2,300 m above sea level at Cachi, Salta, Argentina where the type locality of Jenynsia maculata Regan is located.
The sister-group relationship between Jenynsia and Anableps Scopoli was first proposed by Parenti (1981), and then corroborated by Ghedotti (1998) who also provided a hypothesis of phylogenetic relationships among the nine species of Jenynsia known at that time. Ghedotti (1998) also provided a hypothesis of the monophyly of Jenynsia and the genus was split in two clades, the subgenera Plesiojenynsia Ghedotti and Jenynsia. After Ghedotti (1998), all the new species of Jenynsia described, J. diphyes, J. onca Lucinda, Reis \& Quevedo, J. tucumana Aguilera \& Mirande, and J. weitzmani Ghedotti, Meisner \& Lucinda were included into his morphological matrix and several new hypotheses of relationships were erected within the subgenus Jenynsia, but the two subgenera proposed by Ghedotti (1998) were always recovered as monophyletic. Lately Köerber \& Azpelicueta (2009) recognized J. pygogramma Boulenger as a junior

\footnotetext{
${ }^{1}$ Fundación Miguel Lillo - Consejo Nacional de Investigaciones Científicas y Técnicas (CONICET), Miguel Lillo 251, San Miguel de Tucumán, CP 4000. Tucumán, Argentina. aguileragaston@gmail.com (GA); mcmirande@gmail.com (JMM)

${ }^{2} \mathrm{KCA}$, Grupo de estudio del Killi Club Argentino, Independencia 443, Villa Ballester 1653, Buenos Aires, Argentina. pablocalvin@yahoo.com.ar(PAC)
} 
synonym of J. obscura (Weyenbergh). Currently there are five species in the subgenus Plesiojenynsia while the other eight species belong to the nominal subgenus Jenynsia.

Species of the genus Jenynsia have very restricted distributions, excepting Jenynsia multidentata (Jenyns) which is present from lowlands up to $1200 \mathrm{~m}$ above sea level in a large area in Argentina, Brazil and Uruguay (Aguilera \& Mirande, 2005). Indeed, J. multidentata is considered as a eurytopic species according to Hued \& Bistoni (2005) following the criteria of Karr et al. (1986), because it can tolerate a wide range of environmental conditions. This characteristic, which can justify the wider distributional pattern shown by this species can also mislead systematic studies in cases in which specimens distributed far from their type locality are considered to represent the same species. Jenynsia multidentata is probably a species-complex that should be better studied.

The objectives of this paper are to describe a new species belonging to the subgenus Jenynsia from Northwestern Argentina, with a coloration pattern that resembles Jenynsia multidentata and to propose a new phylogenetic hypothesis based on a reanalysis of the morphological matrix by Ghedotti (1998) including data for the new species herein described. In the matrix by Ghedotti (1998), Jenynsia maculata had several missing entries, which are herein coded from observations of cleared and stained specimens.

\section{Material and Methods}

Specimens were cleared and counterstained (C\&S) following Taylor \& Van Dyke (1985). Measurements are straight distances taken with caliper to nearest $0.1 \mathrm{~mm}$, following Aguilera \& Mirande (2005), and expressed as percents of standard length (SL) in Table 1 . Nomenclature of the sensory canal system follows Gosline (1949). The last two rays in the anal fin of females and dorsal fin of all specimens were counted as separate elements following Ghedotti \& Weitzman (1995). The number of vertebrae includes the hypural complex as one element, and the gill rakers were counted from the ventral limb of first gill arch. Numbers in brackets following the counts indicate the number of specimens for each count; and an asterisk indicates counts of the holotype. The cladistic analyses were performed under equal and implied weighting in a wide range of concavities (constant K) (Goloboff, 1993 ) with the same protocol followed by Aguilera \& Mirande (2005). Clade support was estimated using both resampling methods and decay indices. For the former the matrix was pseudoreplicated with Symmetric Resampling and the supports are expressed as GC values (groups present/contradicted) (Goloboff et al., 2003). The relative Bremer support was used as decay index, given that this considers both information supporting as contradicting each node and also because it gives values that are comparable between analyses under equal and implied weighting (Bremer, 1994; Goloboff \& Farris, 2001). Multistate characters, whose states follow a logical sequence (i.e., could be interpreted as nested homologies) were considered as additive (characters 19, 30, 40, 46, and 58 of Ghedotti's 1998 matrix). The analyses were rooted in Profundulus labialis
(Günther), and the outgroup also includes Fluviphylax obscurus Costa, Aplocheilichthys spilauchen (Duméril) and Alfaro cultratus (Regan). The analyses were performed using TNT software (Goloboff et al., 2008) both with and without constraints in the outgroup structure as used by Ghedotti (1998). We split the transformation series of character 46 , as previously done by Aguilera \& Mirande (2005), as:

Character 46: Length of anal-fin ray five in adult male: (0) long, approximately as long as ray three; (1) intermediate, between one-quarter and three-quarters length of ray three; (2) short, less than one-quarter length of ray three.

Character 71: Symmetry of anal-fin ray five in adult male: (0) symmetric; (1) asymmetric, with one side short and the other side intermediate.

Lucinda et al. (2006) considered that "this change violates the assumption of character-state independence". However, the character 46 is only applicable to the species whose males have a symmetric fifth anal-fin ray and these species can logically have any of the possible states of that character. Therefore, the assumption of independence is not violated because no coding of each of these characters determines logically some specific state in the other one. Thus, the critics by Lucinda et al. (2006) are unfounded and the same character definitions used in Aguilera \& Mirande (2005) are applied in this paper. Following this criterion, species with an asymmetric anal-fin ray 5 in adult males were codified with missing entries for character 46.

We found that character 51 (protuberance on tip of tubular gonopodium formed by anal-fin ray eight) was incorrectly coded by Ghedotti (1998) and this mistake was transferred to subsequent papers dealing with the phylogeny of Jenynsia. In the data matrix by Ghedotti (1998) this character was coded as if all the species of Anableps and Jenynsia unitaenia Ghedotti \& Weitzman, J. eirmostigma Ghedotti \& Weitzman and J. eigenmanni (Haseman) lacked the protuberance on tip of gonopodium (i.e., character state $1=$ absent) and all the remaining species of Jenynsia have that protuberance (i.e., character state $0=$ present), inversely relative to the description of that character in the text. This mistake did not produce consequences on the original phylogeny by Ghedotti (1998), given that all zeroes became ones and vice versa. However, this error produced errors in the new species described after Ghedotti (1998), because their authors coded this character as described in the body text (i.e., with the zeroes and ones inverted relatively with the data matrix). In the present analysis we re-code the character 51 for all the species in the data matrix, assigning the character state " 0 " (presence of a protuberance on tip of gonopodium formed by anal-fin ray eight) to all Anableps species and to J. diphyes, $J$. eigenmanni, Jenynsia eirmostigma, J. unitaenia, and $J$. weitzmani, and the character state "1" (absence of the protuberance on tip of gonopodium) to $J$. alternimaculata (Fowler), J. lineata (Jenyns), J. maculata, J. multidentata, $J$. obscura, J. onca, J. sanctaecatarinae Ghedotti \& Weitzman 
and J. tucumana. As in the paper by Ghedotti (1998) the root of the analysis is coded as a missing entry ("?") for this character.

Abbreviations for ichthyological collections in which the examined specimens are deposited are the following: AI: Asociación Ictiológica, La Plata; ANSP: Academy of Natural Sciences of Drexel University, Philadelphia CI-FML: Fundación Miguel Lillo, Tucumán; and MACN: Museo Argentino de Ciencias Naturales "Bernardino Rivadavia”, Buenos Aires.

\section{Results}

\section{Jenynsia luxata new species}

Fig. 1

Holotype. CI-FML 5464, 24.6 mm SL, male, Argentina, Tucumán, Burruyacu city, a small unnamed stream, río Tajamar basin, 26030'13.47”S 6444'8.75”W, Apr 2002. L. Lobo.

Paratypes. AI 234, 4, 28.0-30.7 mm SL; CI-FML 5465, 6 (2 C\&S), 20.9-29.1 mm SL; and MACN-Ict 9769, 5, 25.1-35.9 mm SL, same data as for holotype. CI-FML 5466, 12 (3 C\&S), 17.3-44.3 mm SL, Argentina, Santiago del Estero, Pellegrini, small flooded pools at Ruta Provincial 4, not connected to but near to río Urueña basin, Mar 2010, P. Calviño.

Diagnosis. Jenynsia luxata is diagnosable from all other members of the genus by the medial processes of left and right pelvic bones relatively reduced, not overlapping each other at ventral midline (Fig. 2). The separation between the medial processes is detectable in fresh and alcohol-preserved specimens by the independent movement of these bones when this region is gently pressed by a needle.

Among the species of the subgenus Jenynsia, the coloration pattern distinguishes $J$. luxata (four to six regular rows of small circular spots of dark brown chromatophores on body side, been more apparent along caudal peduncle) from $J$. alternimaculata (two or, occasionally, three rows of dorsoventrally elongate markings on lateral body surface), J. lineata (five to seven rows of elongate, horizontal dash-shaped markings on side), $J$. maculata (three or four irregular series of more or less oblong blackish spots), $J$. multidentata (five to seven rows and also lines formed by round or short, horizontal dash-shaped markings, more than four scales in length on ventral caudal peduncle), $J$. onca (distinct ovoid to circular dark spots confined to ventral half of flank posterior to pelvic fin; spots gradually more circular towards midventral line), and J. tucumana (a row of dark markings ranging from dots to small vertical stripes, on the lateral surface, from the tip of the adpressed pectoral fin to the margin of hypural). Jenynsia luxata is also distinguishable from $J$. multidentata and $J$. lineata by the absence of a swelling between the urogenital opening and the anterior base of the anal fin in females; from $J$. obscura by the lower number of predorsal scales (12-16 vs. 1925 ); from $J$. onca by the absence of a large dorsal convex expansion at subdistal segments of right half of sixth anal-fin ray of adult males and the smaller eye diameter of females (26.1$33.1 \% \mathrm{HL}$ vs. $33.5-40.0 \% \mathrm{HL}$ ); and from $J$. lineata and $J$. sanctaecatarinae by the absence of a distinct rounded spot on dorsal pectoral-fin base.

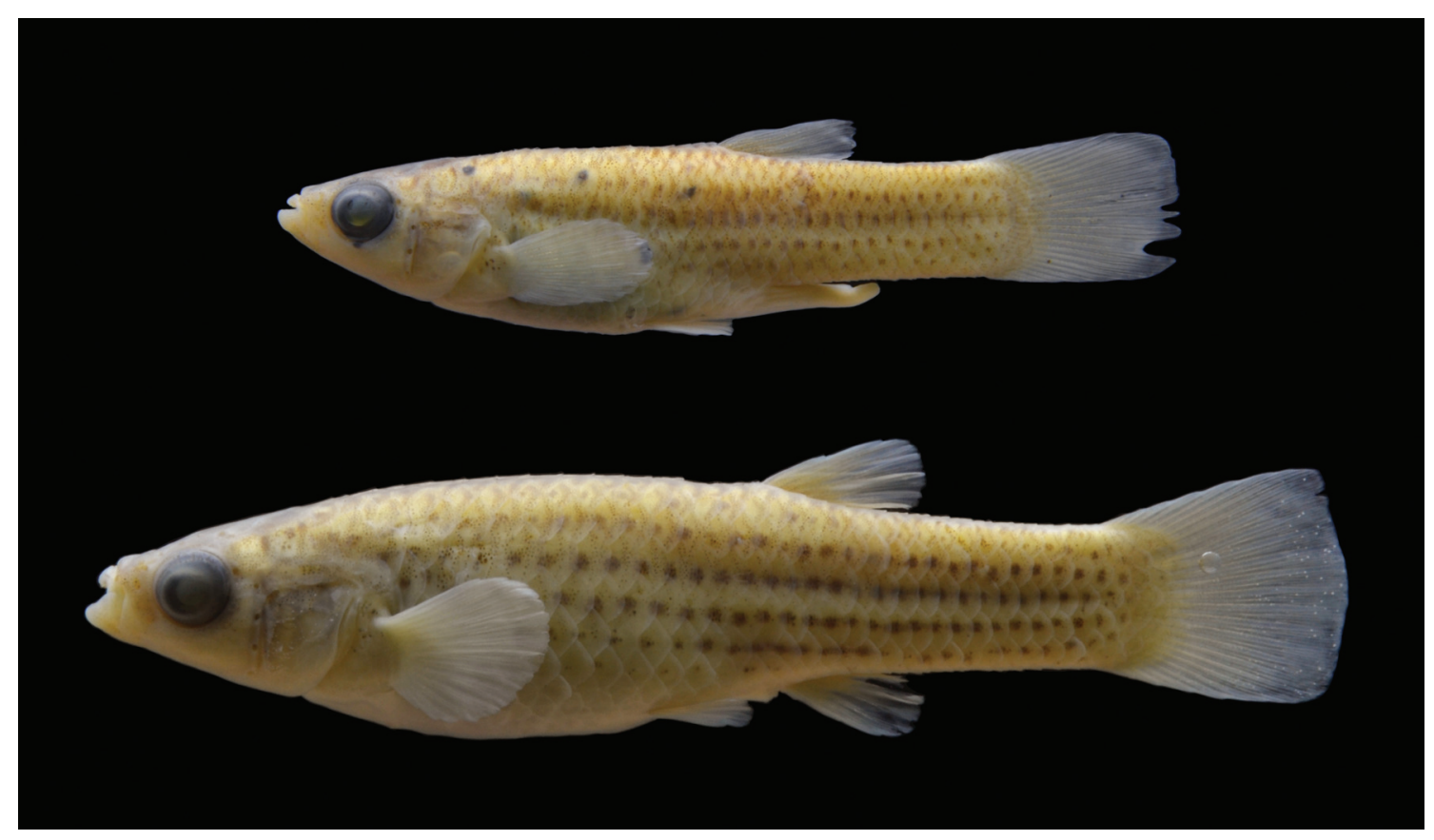

Fig. 1. Jenynsia luxata. Above: holotype CI-FML: 5464, male, $24.4 \mathrm{~mm}$ SL, Tucumán, Burruyacu city, a small unnamed stream, río Tajamar basin, Argentina; below: paratype CI-FML 5466, female, $34.8 \mathrm{~mm}$ SL, Santiago del Estero, Pellegrini, small flooded pools at Ruta Provincial 4, not connected to but near to río Urueña basin, Argentina. 
Description. Body stout and laterally compressed posteriorly; greatest body depth slightly anterior to pelvic-fin origin. Head blunt; head squamation in Fig. 3. Mouth terminal to slightly oblique. Dorsal profile of body straight from snout tip to supraoccipital process, straight to concave to dorsal-fin origin, and slightly convex backwards to caudal-fin origin. Ventral profile of body slightly concave from snout tip to isthmus, more pronounced to pelvic-fin origin, oblique backward along anal-fin base, and almost straight to caudal-fin origin. Anal-fin insertion located slightly posterior to vertical line through dorsal-fin origin. Sexual dimorphism present, males smaller than females and with intromittent organ formed by first eight analfin rays. Dorsal-fin insertion in females at halfway between pelvic and anal fins, in males closer to anal-fin origin. Pelvic fin reaching anus in females and reaching base of gonopodium in males. Absence of swelling between urogenital opening and anal-fin base of females.

Pores of cephalic sensory system associated with lateral sensory system anterior branch of supraorbital sensory canal formed by pores 1 and $2 \mathrm{a}$; middle part by $2 \mathrm{~b}, 3$, $4 \mathrm{a}$, and posterior branch by $4 \mathrm{~b}, 5,6,7$; preopercular canal continuous, with 7 pores; infraorbital canal formed by 4 pores; mandibular canal with pores $\mathrm{X}, \mathrm{Z}, \mathrm{W}$, and pores $\mathrm{Ya}$ and $\mathrm{Yb}$ separated or included, in small specimens, in open groove; tricuspid teeth in both premaxilla and dentary.

Morphometric data in Table 1. Dorsal-fin rays 8 (1) or 9 $(24 *)$. Anal-fin rays in females 10 (17). Principal caudal-fin rays $14(5), 15\left(9^{*}\right)$, or $16(11)$. Pectoral-fin rays 14 (3), 15 (12), or $16\left(10^{*}\right)$. Pelvic-fin rays $6\left(25^{*}\right)$. Lateral line $30(4), 31\left(11^{*}\right)$, 32 (8), or 33 (2). Predorsal scales 12 (2), 13 (8*), 14 (11), $15(3)$, or $16(1)$. Circumpeduncular scales $16\left(25^{*}\right)$. Vertebrae $28(1)$, 29 (2), or 30 (2). Epipleural ribs 9 (2), 10 (2), or 11(1). Pleural ribs 11 (1), 12 (1), or 13 (3). Gill rakers 13 (2), or 14 (1).

Coloration in alcohol. Body background yellowish, grading from brown or pale brown dorsally to cream ventrally. Head dorsum from snout tip to vertical line through anterior eye margin dark brown but paler than area between eyes to supraoccipital process, having very distinct concentration of dark brown chromatophores. Cheek and area posteriorly surrounding eye pale brown or cream. Concentration of dark brown chromatophores on upper margin of opercle. Scales on body, from dorsum to second row behind lateral line with concentration of dark brown chromatophores bordering scales on their posterior field, forming reticulated pattern. Body side with circular spots or short dash-shaped markings of dark brown chromatophores in center of each scale, which coalesce in some specimens forming continuous lines and arranged into 4 to 6 regular rows along caudal peduncle. Rows of chromatophores less evident on anterior portion of body. Midlateral row more evident than remaining ones. Belly unpigmented, only peritoneal coloration visible at midventral line through body wall. Absence of diffuse dark chromatophores on dorsal pectoral-fin base. All fins hyaline, but having scattered chromatophores following rays on dorsal, caudal, and pectoral fins. Scattered chromatophores on gonopodium from its base to tip.

Distribution. The new species is currently known to inhabit the endorheic río Tajamar or río Cajón basin near to Ruta Provincial 304, at Burruyacu, northeastern Tucumán, and also in small flooded pools not connected but near to río Urueña basin, in northwestern Santiago del Estero (Fig. 4). Despite several collecting expeditions to the area and extensive sampling by the authors, no additional specimens were found.

Etymology. The specific name "luxata" derives from the Latin, meaning dislocate, in allusion to the diagnostic character of the species herein described, the separate pelvic bones.

Phylogenetic relationships. The morphological data matrix is presented in Table 2. The assignments of character states exhibited by specimens of Jenynsia maculata showed some differences with that by Ghedotti (1998): the fifth anal-fin ray of adult males is approximately as long as the third (46-0), the gonopodium lacks a protuberance on its tip formed by anal-

Table 1. Descriptive morphometrics of Jenynsia luxata. $\mathrm{SD}=$ standard deviation.

\begin{tabular}{|c|c|c|c|c|c|c|c|}
\hline \multirow{2}{*}{ Character } & \multirow{2}{*}{ Holotype } & \multicolumn{3}{|c|}{ Males Paratypes $(n=8)$} & \multicolumn{3}{|c|}{ Females Paratypes $(\mathrm{n}=16)$} \\
\hline & & Range & Mean & SD & Range & Mean & SD \\
\hline Standard length $(\mathrm{mm})$ & 24.4 & $17.3-30.4$ & 22.8 & & $26.5-44.3$ & 33.4 & \\
\hline \multicolumn{8}{|c|}{ Percents of standard length } \\
\hline Head length & 28.9 & $25.4-29.4$ & 27.8 & 1.4 & $26.9-29.3$ & 28.1 & 0.8 \\
\hline Predorsal length & 60.0 & $60.0-64.5$ & 62.2 & 1.8 & $63.7-68.3$ & 65.9 & 1.4 \\
\hline Snout to pectoral fin & 31.3 & $29.2-33.2$ & 31.3 & 1.3 & $27.9-32.9$ & 30.0 & 1.4 \\
\hline Snout to pelvic fin & 51.4 & $48.3-56.4$ & 52.8 & 2.3 & $52.8-58.3$ & 55.6 & 1.6 \\
\hline Peduncle depth & 16.6 & $15.0-17.4$ & 16.4 & 0.9 & $13.8-16.5$ & 14.8 & 0.7 \\
\hline Caudal peduncle & 34.1 & $32.2-36.2$ & 34.2 & 1.3 & $26.1-33.0$ & 29.7 & 2.1 \\
\hline Gonopodium length & 26.5 & $21.8-30.5$ & 25.9 & 2.6 & - & - & - \\
\hline \multicolumn{8}{|c|}{ Percents of head length } \\
\hline Snout length & 25.2 & $19.3-29.9$ & 25.9 & 3.9 & $25.3-33.3$ & 28.8 & 2.2 \\
\hline Post orbital length & 44.5 & $42.4-54.2$ & 47.5 & 3.8 & $42.0-48.6$ & 46.0 & 1.7 \\
\hline Eye diameter & 33.1 & $31.0-39.2$ & 34.6 & 2.8 & $26.1-33.1$ & 29.2 & 1.7 \\
\hline Interorbital width & 45.3 & $41.4-57.8$ & 47.7 & 5.4 & $42.3-51.3$ & 46.7 & 2.4 \\
\hline
\end{tabular}




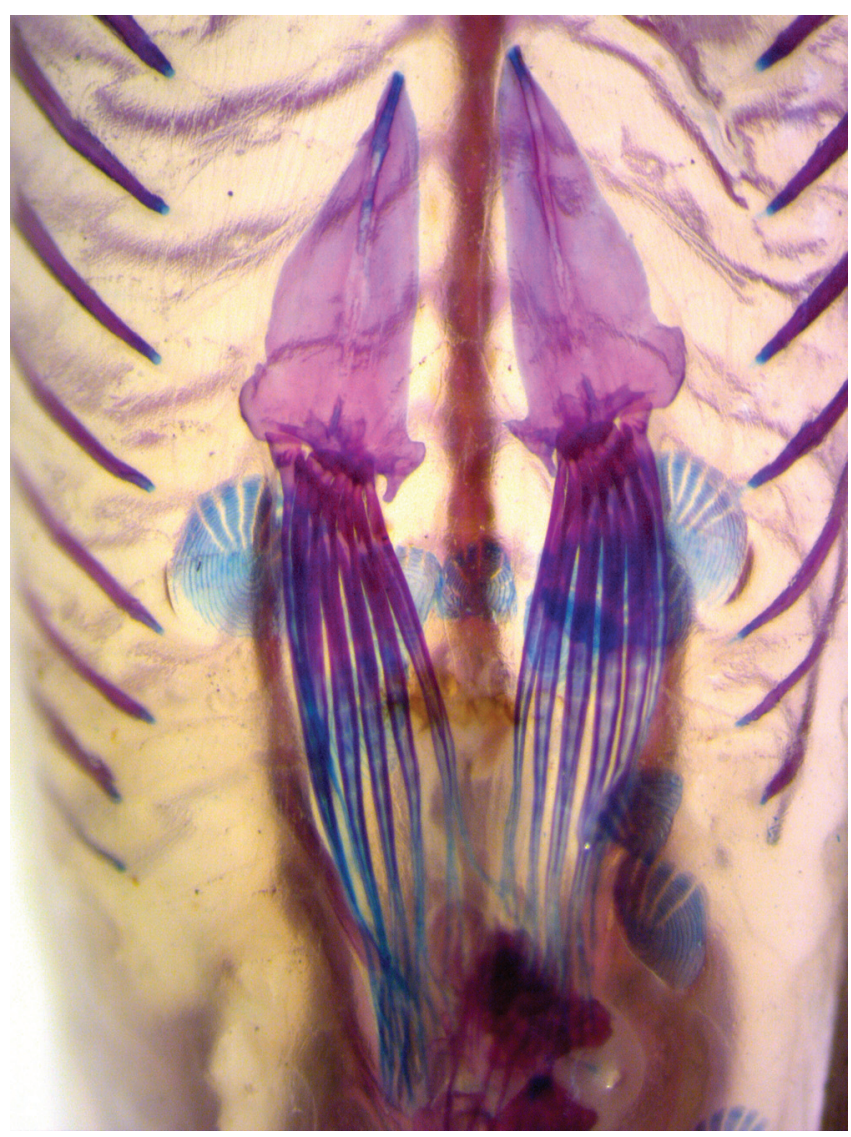

Fig. 2. Pelvic girdle of Jenynsia luxata, paratype, male, CI-FML 5465, $27.8 \mathrm{~mm}$ SL.

fin ray eight (51-1), the hypurals are fused in adults, forming two symmetrical dorsal and ventral hypural elements (59-1), the pore $\mathrm{W}$ of the mandibular canal can be both present or absent (60-[01]), there is a series of three or more narrow lines composed of short, dash shaped marking (64-2), and the swelling between urogenital opening and anterior anal-fin base is absent (69-0).

Under equal weights, 12 equally most parsimonious trees of 154 steps were found $(\mathrm{CI}=0.58 ; \mathrm{RI}=0.78)$. The topology of the consensus tree (Fig. 5A) is the same as the proposed by Lucinda et al. (2006) for the subgenus Plesiojenynsia, with $J$. unitaenia as the sister species of a polytomy including $J$. diphyes, J. weitzmani, and a clade composed of J. eigenmanni and J. eirmostigma. The subgenus Jenynsia is more resolved than in previous phylogenies, with a trichotomy at the base including $J$. maculata, $J$. sanctaecatarinae, and a clade composed of the remaining species of the subgenus. The latter clade also forms a trichotomy, composed of J. luxata and $J$. onca and two nodes including $J$. lineata and $J$. multidentata, and a trichotomy between J. alternimaculata, $J$. obscura, and J. tucumana, respectively.

Under implied weighting, two equally most parsimonious trees of 154 steps $(C I=0.58 ; R I=0.78)$ were obtained with each concavity $(\mathrm{K})$, in the range from 4 to 20 . The strict

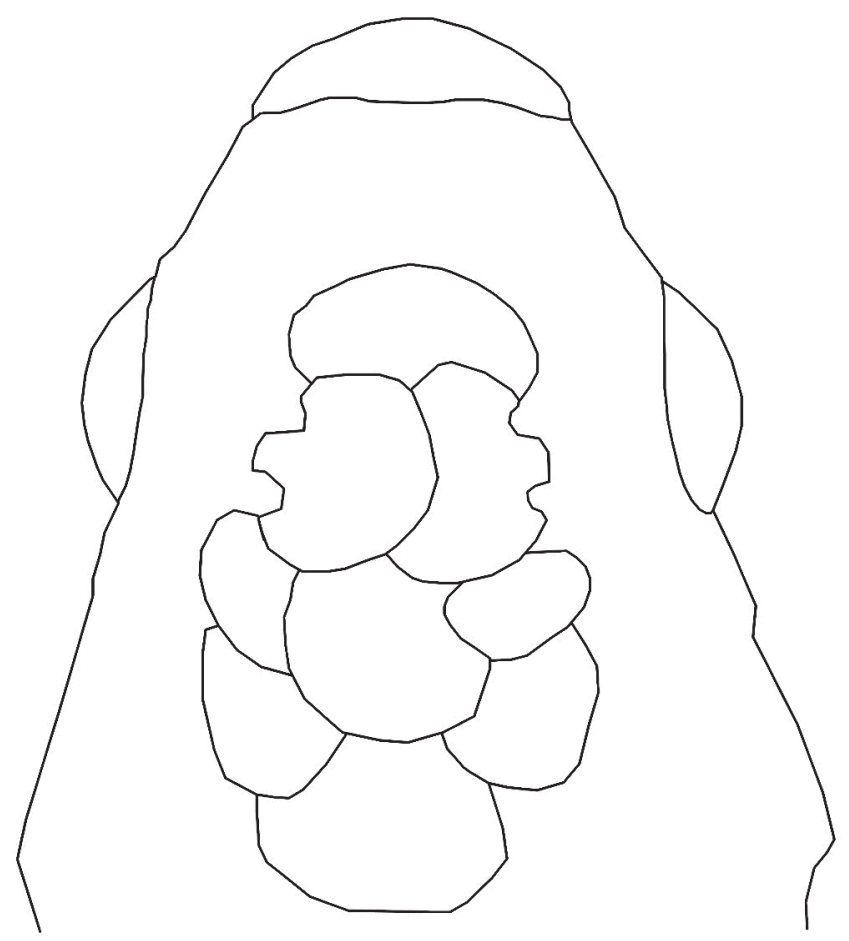

Fig. 3. Diagrammatic representation of head squamation of Jenynsia luxata.

consensus between these equally most parsimonious trees is completely resolved for the subgenera Plesiojenynsia and partially resolved for Jenynsia (Fig. 5B). Within Plesiojenynsia, J. diphyes, J. unitaenia, and J. weitzmani are successive sister species of a clade composed of $J$. eigenmanni and J. eirmostigma. In the subgenus Jenynsia, $J$. maculata, J. sanctaecatarinae, J. onca, and J. luxata are successive sister groups of a clade composed of J. tucumana, $J$. alternimaculata, and $J$. obscura as the sister group of a clade composed of $J$. lineata and J. multidentata.

\section{Discussion}

Jenynsia luxata exhibits the three synapomorphies considered by Ghedotti (1998) as diagnostic for the subgenus Jenynsia: (1) a modified sixth anal-fin ray segmented on its proximal quarter; (2) unsegmented on its distal quarter in adult males and (3) the vertically inclined proximal radials associated with the first six anal-fin rays in the gonopodium. These character-states are unique and unreversed in the subgenus Jenynsia. In the present analyses, both under equal and implied weighting, additional synapomorphies support the monophyly of the subgenus Jenynsia: a long and somewhat narrow, expanded medially and narrow laterally posterodorsal process of palatine in dorsal view (character state 17-1); left and right halves of anal-fin ray six in adults males not laterally paired, and with 


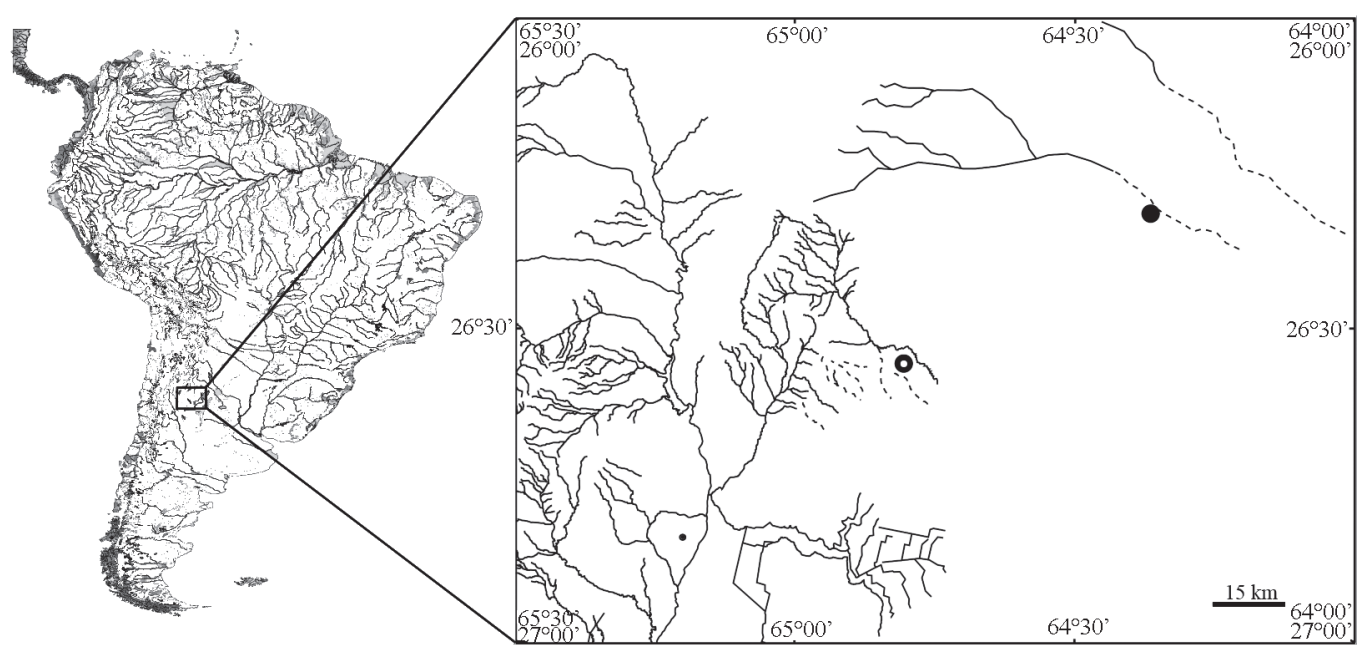

Fig. 4. Hydrographic map of South America showing the currently known distribution of Jenynsia luxata. The area delimited by the rectangle is enlarged at right, where the type locality is indicated by an open dot and an additional locality is indicated by a black dot. The small black dot indicates the capital of Tucumán.

both sides expanded and visible externally (character state 47-1); absence of a protuberance on the tip of gonopodium formed by anal-fin ray eight (character state 51-1); and presence of a series of three or more narrow lines not associated with distinct midlateral stripe on caudal peduncle, composed of short, dash shape markings (character state 64-2). The character 17 presents a reversion in Jenynsia obscura (character state 1 to 0 ); the character 47 has a transformation to state 2 in $J$. onca and a reversion to state 0 in the clade composed of J. multidentata and J. lineata; the character 51 is reversed to state 0 in $J$. onca; and the character 64 has a transformation to state 1 in J. multidentata and a reversion to state 0 in the clade composed of $J$. tucumana, $J$ altenimaculata, and $J$ obscura.

The medial process of left and right pelvic bones not overlapping each other is a unique character in Jenynsia that only can be found in the closely related genus Anableps, among the Anablepidae. This character is optimized in the phylogeny of the family as a parallelism between Anableps and Jenynsia luxata.

Table 2. Morphological data matrix. $\mathrm{A}=$ polymorphic character, states 0 and $1 ; \mathrm{B}=$ polymorphic character, states 0 and 2 ; ?= missing character.

\begin{tabular}{|c|c|c|c|c|c|c|c|c|}
\hline & $1-10$ & $11-20$ & $21-30$ & $31-40$ & $41-50$ & $51-60$ & $61-70$ & 71 \\
\hline Profundulus labialis & 0000000000 & 0000000000 & 0000000000 & 0000000000 & 0000000000 & $? ? 00000000$ & 0000000000 & 0 \\
\hline Alfaro cultratus & 0100000000 & 0000000010 & 0000000000 & 0000110102 & 2011000000 & $? ? 0000021 ?$ & $? 000000001$ & 0 \\
\hline Aplocheilichthys spilauchen & 0100110001 & 00010000A1 & 0001100000 & 0000100000 & 0000000000 & $? ? 00000010$ & $? 000000000$ & 0 \\
\hline Fluviphylax obscurus & $00002 ? 0102$ & 0000000020 & 0000100102 & 0000110004 & 0000000000 & $? ? 0000020 ?$ & $? 000000000$ & 0 \\
\hline Oxyzygonectes dovii & 0100100011 & 0100000010 & 0101001000 & 0000001000 & 0000000000 & $? ? 00000010$ & 0000000100 & 0 \\
\hline Anableps dowi & 1011111011 & 1111012112 & 1111001010 & 1011311111 & 1101000001 & 0010001210 & 1300111101 & 0 \\
\hline Anableps anableps & 1011111011 & 1011112112 & 1111011010 & 1111111111 & 1101000001 & 0010001210 & 1001111101 & 0 \\
\hline Anableps microlepis & 1011111011 & 1011112112 & 1111011010 & 1111111111 & 1101000001 & 0010001210 & 1001111101 & 0 \\
\hline Jenynsia unitaenia & 0000110011 & A100000001 & 0100100001 & 0000201002 & 1011110000 & 00100101A0 & 0100000101 & 0 \\
\hline Jenynsia weitzmani & 0000010A11 & 0100000001 & 0100100001 & 0000201003 & 1011110000 & 0010110111 & 0100000101 & 0 \\
\hline Jenynsia onca & 0000100001 & 0100001010 & 0101100100 & 0000001002 & 1011022110 & 0111010110 & 0002000101 & 0 \\
\hline Jenynsia eirmostigma & 0000010111 & 0100000001 & 0100A00102 & 0000201003 & 1011110000 & 00101101A1 & 0210000101 & 0 \\
\hline Jenynsia eigenmanni & 0000010111 & 1100000001 & 0100100101 & 0000201003 & $10111 ? 0000$ & 00101101A1 & 0210000101 & 1 \\
\hline Jenynsia sanctaecatarinae & 0000110011 & 0100001010 & 0101100000 & 0000101002 & $10110 ? 1110$ & 1111010110 & 0002000101 & 1 \\
\hline Jenynsia alternimaculata & 0000010001 & 0100001010 & 0101100000 & 0000B01002 & $10110 ? 1110$ & 11110101A1 & 0000000101 & 1 \\
\hline Jenynsia obscura & 0000000012 & 0100000000 & 0101100000 & 0000201102 & 1011021110 & 1111010101 & 0110000111 & 0 \\
\hline Jenynsia multidentata & 0000A10A11 & A1000010A0 & 0101100000 & 0000001002 & 1010020110 & 1111010100 & 0001000111 & 0 \\
\hline Jenynsia lineata & 0000010111 & A100001010 & 0101100000 & 0000001002 & 1011020110 & 1111010100 & 0002000111 & 0 \\
\hline Jenynsia tucumana & 0000010011 & 0100001010 & 0101100000 & 0000?01002 & 1011021110 & 1111010100 & 0010000101 & 0 \\
\hline Jenynsia diphyes & 0000110011 & 0100000001 & 0100100000 & 0000201002 & 1011110000 & 1010110111 & 0210000101 & 0 \\
\hline Jenynsia maculata & 0000000011 & 0100001010 & 0101100001 & 0000?01002 & 1011001110 & 101101011A & 0002000101 & 0 \\
\hline Jenynsia luxata & 0000100011 & 0100001010 & 0101100000 & $0000 ? 01012$ & 1011021110 & 1111010100 & 0001000101 & 0 \\
\hline
\end{tabular}



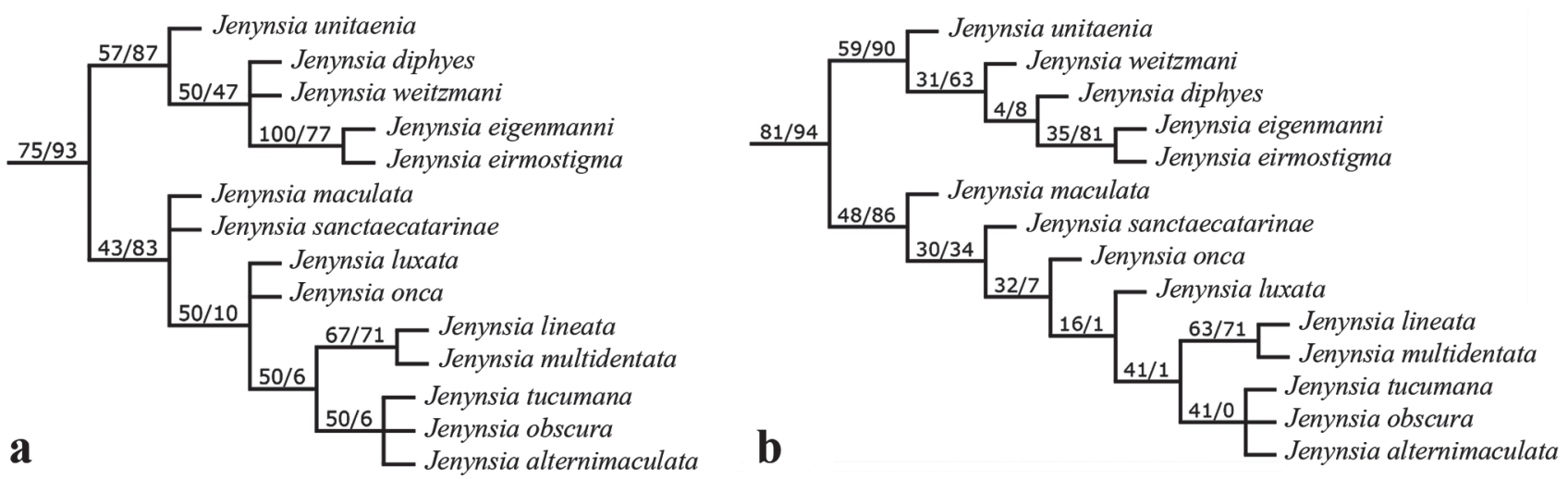

Fig. 5. Topologies from most equally parsimonious trees and relative Bremer support/GC values under (a) equal weights (strict consensus of 12 trees), and (b) implied weighting (strict consensus of two trees), with concavities $\mathrm{K}=4$ to 20 (with supports measured under $\mathrm{K}=8$ ). Unsupported nodes are shown as collapsed. The relationships of genera of the family are consistent with those proposed in previous studies, therefore species of Anableps and Oxyzygonectes are not shown.

Regarding the protuberance on the tip of gonopodium formed by anal-fin ray eight (character 51), only J. tucumana and $J$. onca were coded with the state 1 (= absence of that protuberance) in the latest published data matrix of the Anablepidae (Lucinda et al., 2006), among the species belonging to the subgenus Jenynsia. However, close examination of specimens of $J$. alternimaculata, J. lineata, $J$. maculata, $J$ multidentata, and $J$. obscura revealed that all these species also lack the protuberance on the tip of gonopodium. Based on this examination, all the above mentioned species were coded as " 1 " (= absent) for the character 51 of the original matrix of Ghedotti (1998). This change in the coding produces a higher resolution on the phylogenetic relationships among the members of the Anablepidae and especially in the subgenus Jenynsia. All the species of this subgenus lack the protuberance on the tip of gonopodium and it represents a new, unreversed synapomorphy for the subgenus Jenynsia.

The obtained topology for the subgenus Jenynsia differs from all previous analyses both under implied weighting and equal weights due to the addition of the new species herein described, the coding of several missing entries for $J$. maculata, and the correction of character 51 in the matrix from Ghedotti (1998). In the phylogenetic hypothesis herein proposed, based both on implied weighting and equal weights, Jenynsia maculata is the sister species of all the remaining species of the subgenus Jenynsia. Changes in the coding of several characters of $J$. maculata, compared with Ghedotti (1998), produced some differences in their optimization in the present analysis. The optimization of these characters is identical in the analyses under both equal and implied weighting. The change in coding of character 46 , from state 2 (in Ghedotti's 1998 matrix) to 0 (in present codification) produced the migration of Jenynsia maculata to a basal position in the subgenus Jenynsia tree topology. In the present phylogenetic hypothesis the state 2 of character 46 is a synapomorphy of the clade including all the species of Jenynsia, excepting $J$. maculata and $J$. sanctaecatarinae.

The character-states 51-1 and 64-2 are herein proposed as new synapomorphies for the subgenus Jenynsia. The character 59 codified according to Ghedotti (1998) matrix (i.e., character-state 0 ) was optimized as a synapomorphy for the subgenus Jenynsia, but it was not recovered given the present coding (i.e., character-state 1). This character-state (59-1) is now a synapomorphy of a deeper node composed of $J$. luxata as the sister group of a clade including $J$. alternimaculata, J. lineata, J. multidentata, J. obscura, and $J$. tucumana. The character-state 69-1, as in the hypothesis of Ghedotti (1998), is a synapomorphy of a clade composed of $J$. lineata and $J$. multidentata.

Jenynsia luxata externally resembles $J$. multidentata, however, besides the medial process of pelvic bones not overlapping, the absence of swelling in J. luxata and several osteological differences between these species allow us to distinguish them. Jenynsia multidentata has a wide distributional range, from río Negro in Argentina to southern Brazil, and there is even a record from Chile (QuezadaRomegialli, 2009) where this species was introduced for mosquito control. Despite the fact that $J$. multidentata was unintentionally introduced in several rivers along its distributional range due to its use as bait, many native populations are in need of additional studies. Some of these populations likely constitute undescribed species.

Comparative material (numbers in parentheses indicate the number of measured specimens): Jenynsia alternimaculata. Argentina. CIFML 3825, 16 (4 C\&S), 20.8-43.7 mm SL, Salta, Orán, río Anta Muerta, tributary of río Blanco, río Bermejo basin. Bolivia. CI-FML 3831, 41 (10), 22.2-37.8 mm SL, Tarija, unnamed river in Acheralitos, which flows to río Cambarí, río Tarija basin. Jenynsia lineata. 
Uruguay. CI-FML 5462, 26 (1 C\&S), 20.9-38.3 mm SL, Maldonado, laguna del Diario. Jenynsia maculata. Argentina. CI-FML 3832, 10 (5), 21.0-30.2 mm SL, Catamarca, Fuerte Quemado, small tributary of río Santa María. CI-FML 4743, 20 (2 C\&S), 15.9-30.4 mm SL, Salta, río Calchaquí, Cachi. Jenynsia multidentata. Argentina. CIFML 1081, 3, 23.0-23.8 mm SL, Tucumán, Lules, arroyo Calimayo (2 km from Ruta Nacional 38). CI-FML 1569, 11 (5), 20.1-43.2 mm SL, Córdoba, arroyo Las Mojarras, $2 \mathrm{~km}$ from lago San Roque. CIFML 3826, 15 (10, 2 C\&S), 28.0-36.5 mm SL, Tucumán, Monteros, río Mandolo, río Salí basin. Uruguay. CI-FML 1440, 36 (10), 19.843.2, Canelones, Canteras de Carrasco. Jenynsia obscura. Argentina. CI-FML 2009, 288 (10), 21.8-54.7 mm SL, Catamarca, Hualfín, Los Nacimientos. CI-FML 5463, 10 (2 C\&S), 27.6-57.8 mm SL, Catamarca, río Vís Vís basin. Jenynsia tucumana. Argentina. CI-FML 3828, holotype, $30.7 \mathrm{~mm}$ SL, Tucumán, Trancas, río Vípos, $5 \mathrm{~km}$ from Ruta Nacional 9. AI 163, paratypes, 6, 26.3-40.4 mm SL; ANSP 180781, paratypes, 6, 20.4-33.0 mm SL; CI-FML 3829, paratypes, 4, 26.2-32.8 mm SL; CI-FML 3840, paratypes, 2 C\&S, 28.3 and 36.0 mm SL; CI-FML 3841, paratypes, 4 C\&S, 20.4-38.5 mm SL, same data as holotype.

\section{Acknowledgments}

We thank G. Suarez for help in collecting expeditions. Consejo Nacional de Investigaciones Científicas y Técnicas (CONICET), Fundación Miguel Lillo and FONCyT (PICT-20081201 granted to J. M. Mirande) partially supported this study. TNT was provided free by the Willi Hennig Society. To Apache OpenOffice, Inkscape, Gimp for providing free softwares that were used in this paper. We also thank two anonymous reviewers for their comments that helped to improve this paper.

\section{Literature Cited}

Aguilera, G. \& J. M. Mirande. 2005. A new species of Jenynsia (Cyprinodontiformes: Anablepidae) from northwestern Argentina and its phylogenetic relationships. Zootaxa, 1096: 29-39.

Bremer, K. 1994. Branch support and tree stability. Cladistics, 10: 295-304.

Ghedotti, M. J. 1998. Phylogeny and classification of the Anablepidae (Teleostei: Cyprinodontiformes). Pp. 561-582. In: Malabarba L. R., R. E. Reis, R. P. Vari, Z. M. S. Lucena \& C. A. S. Lucena (Eds.). Phylogeny and Classification of Neotropical Fishes. Porto Alegre, Edipucrs.

Goloboff, P. A. 1993. Estimating character weights during tree search. Cladistics, 9: 83-91.
Goloboff, P. A. \& J. S. Farris. 2001. Methods for quick consensus estimation. Cladistics, 17: S26-S34.

Goloboff, P. A., J. S. Farris, M. Källersjö, B. Oxelman, M. J. Ramírez \& C. A. Szumik. 2003. Improvements to resampling measures of group support. Cladistics, 19: 324-332.

Goloboff, P. A., J. S. Farris \& K. C. Nixon. 2008. TNT, a free program for phylogenetic analysis. Cladistics, 24: 774-786.

Gosline, W.R. 1949. The sensory canals of the head in some cyprinodont fishes, with particular reference to the genus Fundulus. Occasional Papers of the Museum of Zoology, University of Michigan, 519: 1-17.

Hued, A. C. \& M. A. Bistoni. 2005. Development and validation of a Biotic Index for evaluation of environmental quality in the central region of Argentina. Hydrobiologia, 543: 279-298.

Karr, J. R., K. D. Fausch, P. L. Angermeier \& P. R. Yant. 1986. Assessing biological

integrity in running waters: a method and its rationale. Illinois $\mathrm{Na}-$ tural History Survey (Special Publication) 5: 1-28.

Köerber, S. \& M. M. Azpelicueta. 2009. On two Jenynsia taxa (Cyprinodontiformes: Anablepidae) from Argentina, originally placed in the poeciliid genus Xiphophorus. Zootaxa, 2028: 5158.

Lucinda, P. H. F., M. J. Ghedotti \& W. J. Graça. 2006. A new Jenynsia species (Teleostei, Cyprinodontiformes, Anablepidae) from southern Brazil and its phylogenetic position. Copeia, 2006: 613-622.

Parenti, L. R. 1981. A phylogenetic and biogeographic analysis of cyprinodontiform fishes (Teleostei: Aterinomorpha). Bulletin of the American Museum of Natural History, 168: 335-557.

Quezada-Romegialli, C., I. Vila \& D. Véliz. 2009. A new invasive freshwater fish species in Central Chile: Jenynsia multidentata (Jenyns, 1842) (Cyprinodontiformes: Anablepidae). Gayana, 73: 233-236.

Taylor, W. R. \& G. C. Van Dyke. 1985. Revised procedures for staining and clearing small fishes and other vertebrates for bone and cartilage study. Cybium, 9: 107-119.

Submitted October 26, 2012 Accepted July 5, 2013 by Paulo Lucinda Published September 30, 2013 